\title{
Abandoning Penal Substitution: A Patristic Inspiration for Contemporary Protestant Understanding of the Atonement
}

\author{
Sergey Koryakin
}

Citation: Koryakin, Sergey. 2021 Abandoning Penal Substitution: A Patristic Inspiration for Contemporary Protestant Understanding of the Atonement. Religions 12: 785. https://doi.org/ 10.3390/rel12090785

Academic Editors: Bradley Nassif, Tim Grass and Joel B. Green

Received: 30 April 2021

Accepted: 2 September 2021

Published: 18 September 2021

Publisher's Note: MDPI stays neutral with regard to jurisdictional claims in published maps and institutional affiliations.

Copyright: (C) 2021 by the author. Licensee MDPI, Basel, Switzerland. This article is an open access article distributed under the terms and conditions of the Creative Commons Attribution (CC BY) license (https:/ / creativecommons.org/licenses/by/ $4.0 /)$.
Department of Christian Ministry and Theology, Moscow Evangelical Christian Seminary, 129327 Moscow, Russia; sergeykoryakin@gmail.com

\begin{abstract}
In recent decades, there has been a resurgent interest among Protestant theologians in the so-called Christus Victor theory of the atonement. Firmly grounded in patristic thought (esp. Irenaeus of Lyons), this understanding of the work of Christ was first studied and formulated by a Swedish Lutheran, Gustaf Aulén, in 1931. Recent works by Darby Kathleen Ray, J. Denny Weaver, Thomas Finger, Gregory Boyd, and others develop Aulén's endeavor and present new versions of the Christus Victor model. These scholars directly or indirectly demonstrate that the main framework of the patristic understanding of atonement was more faithful to Scripture and less problematic in terms of dogma and ethics than the traditional Protestant penal substitution theory. A short analysis of contemporary versions of the Christus Victor motif shows that this model of atonement proves to be more relevant in responding to the challenges of today's world by providing substantial background for Christian spiritual life and ethics.
\end{abstract}

Keywords: atonement; the work of Christ; retributive justice; penal substitution; satisfaction; nonviolence; Christus Victor; Gustaf Aulén; Anselm; Irenaeus; Darby Kathleen Ray; J. Denny Weaver; Thomas Finger; Gregory Boyd

Recent decades have shown a resurgent interest in the doctrine of atonement among Protestant theologians. The growing number of conferences and books dedicated to the issue demonstrates an attempt by some authors either to reconsider the centrality of the penal substitution model for a Protestant understanding of the Gospel, or to totally disqualify it by showing the lack of substantial biblical grounding for it. In every century since the Reformation one might easily trace that there were opponents to what we may call the traditional Protestant theory of atonement. The last half of the 19th century and the first decades of the 20th century were marked by an unprecedented number of scholarly attempts to provide alternative interpretations of the work of Jesus Christ. As an alternative to penal substitution, with its accent on the objective side of atonement, the works of Campbell (1856); Bushnell (1866); Ritschl (1872); Moberly (1901); Rashdall (1919) and others tended to emphasize the subjective aspect, thus resuscitating and reinterpreting well known Abelardian views. However, a really new, Copernican approach to the topic was a small book by a Swedish theologian Gustaf Aulén, Christus Victor, published in 1931, in which he showed the importance of the patristic interpretation of the atonement "as a Divine conflict and victory; Christ-Christus Victor-fights against and triumphs over the evil powers of the world, the 'tyrants' under which mankind is in bondage and suffering, and in Him God reconciles the world to Himself" (Aulén 2003, p. 4). This work opened new horizons for contemporary interpreters of the doctrine of the atonement.

This article will attempt to demonstrate basic conceptual differences between the penal substitution and Christus Victor models of the atonement. Without going into details of polemics between the adherents of both views, we will focus on a new tendency among Protestant theologians to appropriate the patristic Christus Victor motif and the overall advantages it brings for Christian doctrine and ethics. 


\section{The Basic Shapes of the Two Approaches to the Atonement}

For an Eastern Orthodox believer, Aulén's approach to the atonement may not seem radically new, because it is akin to the Russian saying, "All that is new is but well-forgotten old". For Western theologians, however, the Christus Victor concept was nothing less than a shift of paradigm. It is well known that the traditional Protestant interpretation of the Cross was ultimately influenced by the ideas of Anselm of Canterbury's Cur Deus homo. ${ }^{1}$ Relatively new to its own time and to the preceding Catholic tradition, this understanding of the person and work of Christ quickly gained popularity among the school theologians and became a basic framework for the Reformers' doctrine of the atonement. One may easily notice the difference of paradigms between the concept espoused by Anselm and the Reformers on one side and by Eastern Fathers on the other.

\subsection{From the Anselmian Satisfaction to Penal Substitution}

The feudal setting of late medieval Europe provided Anselm of Canterbury with the language and concepts for explaining the doctrine of the atonement to his contemporaries. According to the logic of Cur Deus homo, God is the Sovereign whose honor was offended by his vassals, Adam and Eve. Once they sinned, they failed to render uprightness of the will to God, which was the only and complete debt of honor owed to Him. They failed to conquer the devil by their obedience, yielded to his temptations and subjected themselves to his will, contrary to the will and honor of God (Anselm 1903, I. 22). Finally, Adam and Eve trampled God's plan with regard to the future of humankind, since all human nature was corrupted through their fall (I.23).

The measure of the injury turned out to be enormous; the first humans had to restore what was taken away from God, but they also had to make certain "compensation for the anguish incurred", which is a satisfaction that is "something which could not have been demanded" of them (I.11). Certainly, there is no chance for humans to restore the way things were or to offer compensation, since they possess nothing that had not been given to them by God. At the same time, for God "it is not right to cancel the sin without compensation or punishment" by compassion alone; otherwise there will be no difference between the guilty and the not guilty, thus showing Him unjust (I.12). It is necessary, therefore, that either satisfaction or punishment followed every sin (necesse est ut omne peccatum satisfactio aut poena sequatur) (I.15).

The situation seems irresolvable: a man who ought to make satisfaction to God is unable to do so; God, the only one capable of making satisfaction, ought not to do so. Therefore, "it is necessary for the God-man to make it" (II.6). Only the God-man Jesus Christ, by way of satisfaction, is able to offer something "not of debt" (nec ex debito), that is, lay down His life. "For God will not demand this of him as a debt; for, as no sin will be found, he ought not to die" (II.11). Thus, Jesus Christ deliberately and obediently dies instead of humans in order to defeat the devil, make satisfaction to God, restore His honor and provide means for the restoration of God's plan with regard to humanity. In order to reward the Son, the Father applies the merits of His saving work to believers through the sacraments of the Church (II.20).

Notably, the devil plays no significant role in Anselm's doctrine of the atonement. Since "neither the devil nor man belong to any but God, and neither can exist without the exertion of Divine power", there cannot be any controversy between God and the devil. If the devil torments man, it does not imply that he has any power over man, but does so because "God in justice permits this" (I.17).

Anselm's interpretation of the atonement had a big impact on Western theology. While theologians before him had tried to use various biblical metaphors and concepts to describe the work of Christ, after Cur Deus homo many aspired to produce a unified and coherent theory. Undoubtedly, Anselm's concept became "the theme on which most later explanations of the redemption are variations" (Burns 1975, p. 289; see also: Pelikan 1985, p. 23) with no exception for the Reformers, whose doctrine of the atonement is "clearly Anselmic with the advance of clarification and refinement" (Hannah 1978, p. 343)2. 
For Martin Luther and John Calvin the concept of retribution still served as the main leading gear of the doctrine, presenting God as insulted by human sin and the necessity for man to make up for it by offering satisfaction. The vector of the redemption, so to speak, was aimed at overcoming estrangement between God and man without implying any real opposition between God and the devil ${ }^{3}$. However, one may notice slight changes in reasoning more aligned with the later developments of Anselm's thought, found in Thomas Aquinas. If the logic of Cur Deus homo requires satisfaction or punishment, the Reformers saw the dilemma of sin being solved by satisfaction through punishment. Unlike Anselm, Luther and Calvin saw the nature of the atonement not in satisfying God's honor, but in resolving opposition between God's justice and human sin.

According to Luther, "God's justice is God Himself" (Luther 1888, WA 6, s. 127), or as Calvin puts it, "God is a just judge" (Calvin 1960, II. 16.1), who cannot allow His law to be violated. Therefore, until satisfaction is offered, sinners remain under God's wrath; they do not deserve His pardon and remain enslaved by the power of sin and the devil. God uses the law and the devil as His instruments in order to induce man to repentance. God's enemy holds legal power over men; he is their accuser while they are in debt to God's justice. In order to save humankind from this predicament, God's Son, Jesus Christ fulfills the demands of the law and bears its curses by taking human sins upon Himself. On the Cross, God's wrath is poured upon Jesus who is made the greatest of all sinners (summus peccator) on behalf of all men (Luther 1892, WA 5. s. 602-3). God the Father punishes His Son in order to demonstrate His justice with regard to sin. Now God's wrath is placated, His benevolence towards men is restored, and He is ready to offer forgiveness and justify anyone who believes in Jesus Christ (Calvin 1960, II. 17.1, 5). The fruits of redemption are further applied through a "wonderful exchange" (Luther 1892, WA 5, s. 608) or "mystical union" (Calvin 1960, III. 11.10), in which man puts on Christ and is being made one with Him through faith.

These are, in a nutshell, the background and the basic tenets of penal substitution theory, which may be called the traditional understanding of the atonement within orthodox Protestantism. No wonder Aulén called it the 'Latin' doctrine, as opposed to 'the classic idea' of the atonement which he grounded in the New Testament texts and the thought of the early Church Fathers.

\subsection{The "Classic Idea" of the Atonement}

According to Aulén, medieval scholastic theology, starting with Anselm, led the Western doctrine of the atonement away from what the Church tradition held for the first millennium. Indeed, it seems more natural to see the Gospels as the story in which God in Christ opposes and conquers the evil powers, thus reconciling the world to Himself, rather than the story of the Divine Son offering satisfaction to the Father's justice.

Aulén masterfully demonstrates the consistency between the narratives of the Evangelists and other New Testament authors as witnessing that the Cross of Christ was decisively God's victory, which sets sinners free from the bondage to sin, death, and the devil. Further, by thoroughly analyzing the thought of Irenaeus of Lyons, who gave the first systematic account of the atonement, the Swedish theologian bridges the span between the New Testament accounts and the later patristic thought on redemption.

According to Irenaeus, God's Son came down from heaven in order to "kill sin, deprive death of its power, and vivify man" so that human beings could "attain to incorruptibility and immortality" (Irenaeus 1885, III. 18.7, 19.1). Having been deceived by the devil, man subjected himself under his power and could not reclaim eternal life for himself. By taking on human flesh, the Word of God who is God Himself (II.13.8), redeemed men by persuasion, not by violence, which is respecting the freedom of human choice and the rights of the devil. He did it not by "snatching away by stratagem the property of another, but taking possession of His own in a righteous (iuste) and gracious manner" (V.2.1). First, through His teaching and life, He made humans "imitators of His works as well as doers of His words" in order to undo the works of the devil who had "alienated us contrary to 
nature, rendering us its own disciples". Secondly, He "has redeemed us through His own blood, giving His soul for our souls, and His flesh for our flesh, and has also poured out the Spirit of the Father for the union and communion of God, imparting indeed God to men by means of the Spirit" (V.1.1).

A few things are notable in this sketch of Irenaeus' understanding of the atonement. First, he sees the purpose of the incarnation in the liberation of men from bondage to evil powers and thus gives men the possibility of attaining incorruption and immortality. This is a striking difference from the views of Anselm and the Reformers, for whom God's Son takes on flesh in order to die, thus satisfying God's honor/justice, clearing man's status before God and re-enacting His salvific plan for the whole of humanity or/and every believer.

Secondly, it seems that Irenaeus operates with a different concept of justice. For Anselm and the Reformers justice is retributive, demanding satisfaction or punishment for sin; for the bishop of Lyons God's justice is restorative, displayed when He acts not violently and coercively, but by taking into account free choice and the will of His creatures.

Thirdly, Irenaeus is far from associating the work of redemption solely with the death of God's Son; he speaks of the death of Christ as fact, without attempting to show how exactly it redeemed men. He focuses on the redeeming value of the earthly ministry of Christ whose mission was not only to gather in Himself (recapitulating) the experience of human life by "sanctifying every age" (III.22.4), but through His humanity to "deprive apostasy of power" (V.24.4) and thus conquer the devil. For Anselm, however, the earthly ministry of Christ seems to be auxiliary, though the God-Man edifies humans through the example of how one "should not depart from righteousness on account of injustices" (Anselm 1903, II. 11). More valuable, however, is His obedience to the Father which led Him to the Cross (ibid., I.8-9). We find the same tendency in Luther and Calvin: though they speak about the importance of Christ's ministry and obedience to God, the way of salvation is ascribed "as peculiar and proper to Christ's death" (Calvin 1960, II.16.5).

Finally, Irenaeus' doctrine emphasizes the role of Christ's resurrection and ascension for the atonement. Being raised up from the dead, God's Son manifested His victory over the powers of evil, death, and corruption, and became the "first-fruits of the resurrection" of all humankind. Ascending on high, Jesus Christ "offered and commended to the Father that human nature which had been found" (Irenaeus 1885, III.19.3) and poured out the Spirit of the Father "for the union and communion of God and man" (V.1.1). It is noteworthy that the bishop of Lyons links the life of Christians with the work of Christ whose passion "gave rise to strength and power" in believers and "conferred on those that believe in Him the power 'to tread upon serpents and scorpions, and on all the power of the enemy" (II.20.3). Seeing Irenaeus' brevity in describing the death of Christ and his eloquence when he talks about the fruits of Jesus' resurrection, one can easily conclude that in his thought the atonement is more about life-giving, rather than sin-bearing, as was the case with Anselm and the Reformers ${ }^{4}$.

Though the latter Fathers may have been using various ideas and metaphors to describe the salvific work of Christ, they mostly stayed within the framework of Irenaeus' concept of the redemption. As Aulén aptly put it, "there are not different theories of the Atonement in the Fathers, but only variant expressions of one and the same basic idea" (Aulén 2003, p. 37). The whole of the patristic thought on the atonement is based on the idea that it is God who seeks to reconcile rebellious men with Himself through the incarnation, ministry, death, resurrection, and ascension of His Son. The problem is not with God's offended honor nor justice, but with men who need redemption from the power of sin, death, and the devil. Another important aspect of this idea is that, according to the Church Fathers, God's justice is demonstrated not when He demands punishment and/or satisfaction, but when He acts nonviolently with respect to the will and rights of the apostate humans and the devil. The just God in Christ prefers to hand Himself over to the devil, thus snatching sinful humans from his dominion, rather than demanding the death of His innocent Son in order to return balance to His infringed justice. 


\section{Contemporary Debate on the Atonement}

Ultimately, Aulén was right that "each and every interpretation of the atonement is most closely connected with some conception of the essential meaning of Christianity, and reflects some conception of the Divine nature" (ibid., pp. 12-13). As he demonstrated in his study, the traditional Protestant penal substitution theory of the atonement, by developing the ideas of Anselm, displayed a somewhat different view of God and His work, thus causing theological unrest in the minds of its opponents ever since the days of Reformation.

Some critics of the penal substitution theory have pointed at the new developments in biblical studies and argued that the proponents of this doctrine continue to interpret the work of Christ through the lens of the Reformers' concepts ${ }^{5}$, despite the evolution of Christian thought. Others have appealed to studies of metaphorical language used to describe the meaning of the Cross. On the one hand, the fact that the New Testament authors employed metaphors does not give much room for a literal reading of the atonement imagery; on the other, the variety of the images shows that the legal metaphors should not be treated as central to the biblical understanding of redemption ${ }^{6}$. Some scholars have highlighted the implicit doctrinal problems in this traditional Protestant understanding of the atonement, while others questioned whether the penal substitution theory provides a good foundation for Christian ethics.

The size of the present work does not allow us to focus on technical issues of the doctrine, such as biblical concepts and metaphors. We will discuss, however, some doctrinal and ethical corollary of the penal substitution theory, which more often fall under the fire of its opponents and which, as we will see, are deeply connected.

\subsection{Penal Substitution and Doctrinal Difficulties}

As has been pointed out, the Protestant penal substitution theory, following Anselm's logic, does not envision any real controversy between God and the devil. The latter holds man in his power as much as God allows him to do it. Thus the vector of human redemption is not directed at conquering the devil and liberating men from his power, but at satisfying God's justice. Consequently, the problem of estrangement between God and human beings lies within God Himself who cannot forgive His creatures before His Son will be punished and offer satisfaction instead of them.

Many critics of the theory naturally raise the question of whether this understanding brings division within the Trinity, by separating the Son from the Father and juxtaposing their properties and ministry ${ }^{7}$. One punishes, while the Other is being punished; One in His holiness and justice demands satisfaction for sin, while the Other in humility and obedience offers this satisfaction; One is showing His divine wrath, while the Other His divine mercy. Thus, the doctrine of penal substitution makes it very difficult to reconcile the character of God the Father with the character of God the Son who manifested unconditional forgiveness, nonviolence and mercy throughout His earthly ministry. If the Son indeed is of one nature with the Father, as the dogma of the Trinity implies, they both should demonstrate a unity of will and action . $^{8}$

Yet another aspect of the theory vulnerable to criticism is its emphasis on the death of Christ at the cost of downplaying the other redemptive aspects of His ministry. As Peter Schmiechen notes, Jesus' announcement of the coming Kingdom, His moral teachings, healings, and resuscitations are considered not as important as His death on the Cross (Schmiechen 2005, p. 113). At the same time His righteous, obedient life bears significance only in as much as it renders Him a blameless sacrifice to the Father and later is imputed to those who will have believed in Him (Calvin 1960, II.16.10; Jeffery et al. 2007, p. 213).

The same is true with regard to Christ's resurrection, which does not fully integrate with the logic of the penal substitution theory and seems to play the role of an addendum to the main theme, "just an epilogue or footnote to the drama of salvation" (Belousek 2011, p. 110). Within the theory, resurrection serves as a proof that satisfaction to the Father has been offered, sin conquered, condemnation cancelled, humans forgiven, Jesus vindicated as the Son of God, the deposit of eternal life made, and assurance of the future resurrection 
given $^{9}$. It appears that all these statements either interpret what happened at the death of Jesus on the Cross or promise the future transformation of man on the basis of his faith in Christ. It is not clear, however, what role is assigned to the resurrection of God's Son in the divine victory over sin, death, and the devil, which are traditionally considered as the main fruits of His redemption of man. Certainly, the resurrection is not seen here as an organic part of contemporary accounts of the penal substitution doctrine. ${ }^{10}$

In fact, this tacitly shows that the problem of $\sin$ in the penal substitution theory is somewhat underestimated. Human predicament is seen as predominantly a moral problem, a debt or guilt which may be overcome through punishment of God's Son. Man's status before God can be cleared when he "grasps the righteousness of Christ through faith, and clothed in it, appears in God's sight not as sinner but as a righteous man" (Calvin 1960, III. 11.2). Though this new life of justification implies the believer's communion with the resurrected Christ, the narrative of the penal substitution doctrine, at least in its many contemporary presentations, does not make such a connection. Partaking in the power of resurrection is not perceived as part of liberation from an objective evil force corrupting man's nature and alienating him from God, rather it is viewed as a source of moral life according to God's rules.

These doctrinal concerns may seem too distant from Christian ethics. However, it is assumed that a believer's moral life should be deeply grounded in an understanding of God's nature, and imitate His character and His acts. Thus we may question, if we do not see unity in the will and acts of the persons of the Trinity, whom should we imitate: the God Father in His holy justice and judgment or the Son in His mercy and forgiveness? Further, if the resurrection of God's Son plays no integral part in the atonement, what conclusion shall we make about the nature and source of our spiritual life and our participation in God's mission for the world? Finally, if the logic of the penal substitution theory submits all aspects of Christ's earthly redemptive ministry to His death on the Cross, what positive ethical implications can we make from the call to imitate Jesus?

The significance of these questions will become more evident as we further evaluate some ethical corollary of the penal substitution theory.

\subsection{Penal Substitution and Christian Ethics}

According to the theory, God's Son becomes a substitute sacrifice, who bears human sins upon Himself and is punished by God the Father instead of sinful men. On account of Jesus' satisfaction on the Cross, sinners obtain imputation of God's righteousness by faith. The Cross becomes the place of transaction and, according to T. Scott Daniels, "if this is the case, then the call for disciples to take up their cross, in the same manner in which Jesus has taken up his, is extremely convoluted" (Daniels 2006, p. 127). In such a case, the followers of Christ cannot imitate their Teacher because His death on the Cross has already appeased the wrath of God and satisfied justice. Thus, faith in the Gospel becomes "a cognitive assent" to a once completed atoning work of Christ that moves a Christian away from "radical redemptive participation in the world" (ibid., p. 129). As J. Denny Weaver rightfully adds: atonement theories driven by the idea of satisfaction tend to structure "the relationship between humankind and God in terms of ahistorical, abstract legal formula". Among all aspects of the Savior's earthly ministry, the work of the atonement is centered around His death, which brings satisfaction to God's justice but "contains nothing that would change injustice in the social order". Human redemption brings a new status to man and sets his destiny beyond earthly existence, but speaks little of his spiritual transformation and engagement in this life. Such understanding of the atonement is a-ethical in its nature (Weaver 2006, p. 9).

The concept of retributive justice underlying the penal understanding of the atonement implies that the idea of retribution is foundational for God's very nature and thus must guide human ethics in social and political life. If God delivers His Son to a violent death in order to satisfy His justice, it seems natural that, guided by the same idea of justice, human society would approve the death penalty or just war ${ }^{11}$. If God is the God of justice, 
He commends the use of force with regard to sinners, criminals, enemies, people of other faiths, etc. Moreover, as some feminist critics have pointed out, in this kind of society violence and victimization can be taken for granted, because the example of Christ teaches people to silently bear violence for the greater good (Brown and Parker 1989, pp. 27-28).

In addition, the retributive view of justice poses a difficulty for our understanding of divine and human forgiveness. If God cannot forgive without punishing His innocent Son, it calls into question the whole concept of forgiveness as we know it. Firstly, forgiveness by definition is free and does not require preliminary satisfaction or punishment. Christians are called to forgive one another as God in Christ forgave them (Eph 4:32), but if they decide to forgive freely, they would act contrary to God's forgiveness as it is understood in the penal substitution theory. Secondly, forgiveness does not presume participation of the third party. Forgiveness is always about resolving the problem between the offended and the offender, and it does not imply a transfer of guilt on the innocent ${ }^{12}$. Otherwise, forgiveness becomes impersonal, the offender does not deal with the consequences of his sin and is not compelled to repent.

When we begin to unpack the logic of the penal substitution doctrine and apply it to the ethical sphere, it becomes apparent that this understanding of the atonement does not connect well with some practical social and moral issues and raises more questions than it answers. Christian practice is deeply rooted in the doctrinal interpretation of God's nature and His works, and if the latter is guided by the concept of retributive justice, it disconnects Christ's ministry from the lives of His followers, makes it possible to justify violence or misrepresent the character of God and the nature of His forgiveness.

\section{The Christus Victor Motif in Contemporary Protestant Theology}

In recent discussions of the atonement, Aulén's Christus Victor study has become a constant point of reference for many Protestant scholars who seek new approaches to the doctrine of the atonement, ones that would be biblically warranted, doctrinally and ethically consistent, and relevant for the challenges of contemporary life. The 'Classic idea' of the atonement, as presented by Aulén in his study, has become for some scholars an impetus for creative appropriations of the patristic legacy.

\subsection{Darby Kathleen Ray and the 'Patristic Model' of Christus Victor}

At the beginning of her study, Deceiving the Devil, Ray rightfully notes that the two previously dominant approaches to the atonement-the objective (penal) and subjective (exemplary) - do not appeal to their feminist and liberationist detractors. The former consider the penal substitutionary view as encouraging violence and abuse, the latter accuse the moral influence view of ethical passivity in the face of injustice and oppression.

Ray proposes her answer by promoting the 'patristic model' of the atonement. In her study, she heavily relies on Aulén's analysis and tries to find a consonance of the patristic ideas with the contemporary problems of evil and violence. Following the Fathers' thought, Ray recognizes the reality and power of evil in human life and its "unjust or avaricious use of power". Through Christ, God not only revealed the true nature of evil and delegitimized its nature, but also opened new possibilities for human beings (Ray 1998, p. 123). The ideas of ransom and deception of the devil seem to captivate Ray's attention. The former exposes the violence and greed of evil, the latter shows God's wisdom in using evil's power against itself (pp. 124-25).

Ray, however, considers the patristic accounts of the atonement as mythologized and thus not much connected with real life. According to her "demythologized" version, Christ opposes not personal evil power, but "the sum total of evil", which includes not only individual sin, but all kinds of interpersonal, communal, institutional and global evil (p. 130). Salvation does not mean as much as "abolition of evil itself but a transformation in one's relationship to evil" (p. 132).

This interpretation unveils a major weakness in Ray's model. If an atonement theory depersonalizes the devil and denies the objective power of evil, it downplays the serious- 
ness of the human predicament and equates salvation with moral perfection. For Ray, liberation from bondage is a trope but not an objective divine action; a person obtains freedom not from real bondage to evil powers, but when his/her being and actions cease to be determined by evil and the person gets the ability to reduce the evil around them. Strangely enough, this part of Ray's Christus Victor theory becomes more akin to the Abelardian moral exemplary model and can be criticized on the same grounds.

Despite this doctrinal inconsistency, Ray's atonement theory offers a very practical interpretation for Christian ethics. It presents redemption as a "profoundly this-worldly affair" (ibid.), implying radical resistance to all kinds of violence and injustice, and transformation of human society by the acts of mercy, love, and civil disobedience.

\subsection{J. Denny Weaver and 'the Narrative Christus Victor'}

Coming from an Anabaptist-Mennonite background, J.D. Weaver naturally proposes a nonviolent paradigm for interpretation of the atonement. After a series of articles published in the 1990s, he published a monograph, The Nonviolent Atonement, in 2001 in which he fully developed his atonement theory.

As Weaver points out, his 'Narrative Christus Victor' model has much in common with Ray's "demythologized" patristic view. Weaver, however, tries to ground his theory in "the narratives of the Gospels and Revelation rather than second- and third-century statements" (Weaver 2011, p. 282). The book of Revelation depicts God's community living in, but not of, this world and a "conflict and victory of the reign of God over the rule of Satan" (p. 27). The narrative of the Gospels portrays the same cosmic confrontation from an earthly perspective, in the ministry of God's Son. Jesus announced the coming Kingdom of God, healed the sick, expelled the demons, taught His followers not to retaliate to evil with more evil, and to love their enemies. All that Jesus said and did posed a threat to the devil's rule (in all its manifestations), so God's enemy tried to eliminate Him by the hands of men on the Cross. However, Jesus' resurrection revealed the reign of God and conquered the devil.

Weaver's understanding of the nature of evil implies that the devil is not a personified being, but "the accumulation of earthly structures which are not ruled by the reign of God (p. 307). He treats evil not as a supernatural ontological power which subjects human beings, but as some human collective moral defect which can be battled by "resisting evil and making the rule of God visible" (p. 312). Thus Weaver's concept describes "salvation and discipleship, not atonement at all" (Finlan 2007, p. 99), and it seems to downplay the question of man's redemption to a matter of personal spiritual growth and correcting the morals of this world.

From another point of view, Weaver's Christus Victor version brings many advantages for Christian doctrine as well as for ethics. It shows that the atonement is not an abstract transactional idea but God's action through Christ within history. Arguing for the nonviolent character of the atonement, Weaver underscores that this is not passive but "assertive and confrontational nonviolence that provides an opponent with an opportunity for transformation" (Weaver 2011, p. 37). This, undoubtedly, shows the strong ethical appeal of this idea of the atonement.

\subsection{Thomas Finger: Christus Victor as Nonviolent Atonement}

Belonging to the same Protestant tradition as Weaver, Thomas Finger for a long time argued that the Christus Victor view of the atonement is the most accurate representation of biblical teaching (Finger 1985, vol. 2, p. 348), and is consonant with the traditional Anabaptist understanding of redemption (Finger 2004, pp. 349-50).

In his exposition, Finger fully relies on Irenaeus' ideas. The devil tricked the first humans and snatched them from God, thus employing "the violent means". On the one hand, humans have become victims of sin; on the other, they are responsible for their choice. Sin itself is a "suprahuman, quasi-personal power" which snatches away from God, subjects them to its own rule, and leads them toward death (Finger 2006, pp. 92-93). 
God allows humans to bear the consequences of their sin, thus judging the sin indirectly and nonviolently "by handing people over to the lords they choose" (p. 94). Yet, the evil forces that punish people this way are at the same time God's enemies whom God works to destroy.

Finger considers all aspects of Christ's ministry important for his atoning work. Jesus recapitulates humanity and "walks the path God originally set before Adam and Eve" (p. 95). He obeys God's commandments, resists the forces of evil, and is defeated by them. He brings atonement "by servanthood and the way of peace" (p. 97). On the Cross, Jesus bears human wrath directly but suffers the judgment upon sin indirectly, as He is taking upon Himself its deadly consequences. The Father and the Son do not act by force but choose nonviolent means to redeem people. God does not inflict punishment on Jesus but allows Him to be afflicted by it (pp. 98-101). Jesus' resurrection (1) reveals the falsehood of political and religious powers who claimed to be the true guarantors of peace, yet crucified the Prince of Peace and God's Messiah; (2) tricks the devil who overstepped his rights by killing the innocent Christ; ${ }^{13}$ (3) gives new life in the Spirit, who destroys the operations of evil forces in human lives and fills their hearts with divine love (pp. 102-3).

Finger's Christus Victor model can be viewed as a creative and contemporary interpretation and implementation of Irenaeus' ideas. Though at times, when using the concepts of direct or indirect punishment, Finger seems to pay debt to the penal view, yet there is no impression that his reasoning is disconnected from the New Testament narratives or patristic thought. While focused on the mechanics of the atonement, Finger's model does not leave aside the practical implication of Christ's work. It shows that the atonement pertains not only to personal and spiritual salvation, but it contributes to the unity of people, teaching them to perceive violence as "central and related to all forms of $\sin ^{\prime \prime}$ (p. 106) and courageously respond to it nonviolently in self-giving love. By doing this, believers and churches can develop alternative behaviors and structures, which would reflect the spiritual and moral transformation brought by Christ's atonement.

\subsection{Gregory Boyd: Christus Victor as a Unifying Model of the Atonement}

In the words of Gregory Boyd, the Christus Victor theory can serve as an "encompassing conceptual model that might reveal an 'inner logic' to all aspects of Christ's work" (Boyd 2006, p. 24).

The whole biblical narrative, Boyd says, presents the earth and its inhabitants as existing in a cosmic war zone. Humans can be liberated from evil forces only through the radical in-breaking of God (pp. 27-28). The powers opposing God can be closely related to "the destructive spiritual force of various social structures and people groups-nations, governments, religions, classes, races, tribes", etc. Therefore, sin is viewed not as a matter of individual behavior, but as a quasi-autonomous power that holds people in bondage (p. 29). The healings, exorcisms, and resuscitations in the earthly ministry of Christ were weakening the power of the devil and advancing God's Kingdom. Through His death and resurrection, Jesus disarmed the evil powers, made public display of them (Col 2:15), and delivered people from bondage to sin and death (Heb 2:14-15). Humans can be saved only when the primary cause of their predicament is removed, which is why Boyd says that Christ's redemptive ministry has a cosmic significance: "Christ has in principle freed the cosmos from its demonic oppression and thus freed all inhabitants of the cosmos who will simply submit to this new loving reign" (Boyd 2006, p. 35). Now all spiritual progress in human life is achieved by partaking in this, God's victory. Thus, in Boyd's presentation of New Testament teaching we see how different aspects of Christ's ministry are joined by the one idea of God's victory over the powers of evil. The lives of the followers of Jesus also should be guided by one idea: that is, to imitate His life, manifest Kingdom values, and engage in His warfare (p. 40).

According to Boyd, the Christus Victor model of the atonement may serve as a unifying principle for the essential truths of other atonement models. Thus Christ died as our substitute (by becoming the new Adam and bearing the consequences of our sin), He 
gave His life as ransom for many (by releasing us from slavery to the devil, sin, and death); He recapitulated humankind (by His obedience, reversing the fall of the old Adam, and giving a new nature to humanity through the Spirit); He healed humanity (by freeing us from the disease of sin, removing our spiritual blindness, and transforming us into His likeness); He demonstrated His righteous stance against all sin (by suffering the violent force of evil for the sake of our sin); He gave us the example of overcoming evil and empowered us to follow Him and participate in the divine nature. Thus, just like so many aspects of Jesus' earthly ministry, the basic ideas of all models of the atonement "can be understood as one thing-overcome evil with good" (pp. 42-45).

Boyd's unifying model seems to present the most successful attempt to engage with the Christus Victor motif. He presents a biblically warranted, doctrinally sound and logically coherent theory, in which he manages to seamlessly integrate all the facets of Jesus' earthly ministry and the advantages of other atonement theories. Boyd shows a clear dependence between human salvation and the ontological cosmic victory of God over the powers of evil. Freedom from sin and new life is not possible without a preceding defeat of the devil through the ministry of Jesus. Finally, Boyd's interpretation of Christus Victor has many practical advantages: (1) it demonstrates that the redemptive ministry of Jesus is to be deeply embedded in the life of the believer-what Jesus did for man directly relates to what is enacted in man and through man who participates in God's victory in his daily endeavors; (2) it not only assures of the reality of evil powers, but shows their impact on many structures and spheres of human life. Christus Victor encourages Jesus' followers "to resist the demonically seductive pull of nationalism, patriotism, culturally endorsed violence, greed, racism and a host of other cultural evils" (p. 48).

\section{4. "Forward, to the Fathers!"}

This motto is ascribed to the well-known Russian Orthodox theologian Georges Florovsky who once called for a creative appropriation of the patristic legacy: "'Following the fathers' always means moving forwards, not backwards; it means fidelity to the patristic spirit and not just to the patristic letter. One must be steeped in the inspiration of the patristic flame and not simply be a gardener pottering around amongst ancient texts" (Florovsky 1972, p. 294). It appears that Aulén's Christus Victor proposal indicated the same intention not only in turning us to a "well-forgotten old" patristic thought on the atonement, but in presenting to us new perspectives relevant to our realities.

At the end of his study, Aulén prophetically stated that "no form of Christian teaching has any future before it except such as can keep steadily in view the reality of the evil in the world, and go to meet the evil with a battle-song of triumph" (Aulén 2003, p. 156). All the contemporary Christus Victor versions, surveyed above, accept this Aulén challenge.

As we have seen, the Christus Victor model and its contemporary interpretations underscore that the main problem of redemption is human bondage to sin, death, and the devil. Consequently, the atonement is not directed at satisfying God's justice, but at conquering the devil, snatching man from the power of evil, and making him available for God's transformational activity. Thus, the atonement is seen as God's continuous act through Christ in the Spirit, where all the persons of the Trinity are united for one purposebringing man back into fellowship with themselves. Without the radical in-breaking of God through Christ, His multifaceted ministry of undoing the grip of evil on human life, and His death and resurrection, it would be useless to conceive of human salvation and the consequent possibility for people to advance God's Kingdom in everyday life. As we have seen, unfortunately, not all presented contemporary interpretations of the Christus Victor motif are consistent in this respect. Ray's and Weaver's "demythologized" views of evil seem to seriously downplay the ethical and doctrinal advantages of this atonement model.

Secondly, the deliverance from the human predicament is not achieved exclusively by the death of Christ. Contrary to that, the Christus Victor view of the atonement holds all aspects of Jesus' ministry (incarnation, life, death, and resurrection) as valuable for human salvation. As Christ successfully opposed the evil powers throughout His ministry, 
He continued the struggle in his death and resurrection. While Jesus' life and teaching gave a substantial background for Christian discipleship, His resurrection had important ontological significance, because it destroyed death and made the powers of the coming age available to believers.

Finally, we have pointed out that the logic of the Christus Victor model is incompatible with the conventional concept of retributive justice, and thus avoids accusations of promoting ideas of violence. The Gospel narratives as well as patristic interpretations of the atonement demonstrate that God achieves His victory over the devil exclusively through nonviolent means. As all contemporary Christus Victor versions show, this concept has a marked ethical potential, because it assumes that one has to participate in the life of the risen Lord through His Spirit. The Christian is to continue the redemptive work of Christ in everyday life by loving, showing mercy and forgiveness, and by opposing all kinds of evil instead of simply enjoying his personal salvation. Thus, this model of the atonement proves to be more relevant to responding to the challenges of today's world, and providing a substantial background for Christian spiritual life and ethics.

Undoubtedly, the Christus Victor paradigm of the atonement meets the concerns associated with the penal substitution theory. It appears that, having gone the full circle, contemporary Protestant theologians have more or less successfully returned to a balanced biblical teaching on the atonement as it was appropriated and explicated by the Church fathers. One may hope that this tendency will provide a common ground to address different doctrinal paradigms of the Christian East and West and contribute to promoting unity among the followers of Christ.

Funding: This research received no external funding.

Institutional Review Board Statement: Not applicable.

Informed Consent Statement: Not applicable.

Data Availability Statement: Data sharing is not applicable to this article.

Conflicts of Interest: The author declares no conflict of interest.

\section{Notes}

1 Attempts to ground the penal substitution theory of the atonement in the patristic legacy seem to be far-fetched. In these interpretations, all too familiar wording, such as 'punishment', 'death', 'for us' and the like seem to be taken out of context without any attempt at aligning them to the Church Fathers' train of thought or the genre of their works. See, for example: (Jeffery et al. 2007, p. 164 ff; Williams 2011).

2 Though the direct influence of Anselm's doctrine of the atonement on the Reformers is debatable, there is enough evidence of Luther's familiarity with Anselm's works. See, for example: (Burnell 1992). Be that as it may, it is widely admitted that the Reformers' thought on the atonement developed within the framework of Anselm's ideas. As Paul Helm aptly puts it with regard to Calvin: "Since in drawing attention to Calvin's Anselmianism no direct influence is evident, perhaps the true explanation of Calvin's language is simply that Anselmianism was 'in the air' in the circles in which he first learned theology, and that he came to believe that this outlook fairly expressed the biblical view". See: (Helm 2008, p. 59).

3 It is clear that with respect to the devil's role in the atonement, both Reformers followed the well known Anselmian paradigm-the enemy's activity is totally subjected to and guided by God. Luther, on the one hand, describes Jesus on the Cross as Christus Victor fighting a marvelous duel (duellum mirabile) with personified powers of evil. Sin, Death, and the Curse attack Christ trying to devour (devorare) Him, but He defeats them with His absolute righteousness, life, blessedness in His own body, in Himself. On the other hand, we find among Christ's enemies the Law (Lex) and the Divine wrath (Divine ira), which Luther identifies with the Curse (Luther. WA 40.I. s. 437-40). Thus, as Paul Althaus aptly points out, "This is an indication of the fact that the powers with which Christ must do battle are ultimately to be understood theocentrically. God's wrath is one of them and is the real threatening and killing power in them all" (Althaus 1996, p. 209-10). We may see the same tendency in Calvin's understanding of the devil as "the minister of divine vengeance" (Calvin 1960, I.14.18) or "the instrument of God's wrath" (ibid., II.4.2). The victory over Satan is won when the death on the Cross satisfies divine justice and deprives the accuser of his legal power over men. See: (Blocher 2004, pp. 290-92).

4 Characteristically Anselm does not actually mention Christ's resurrection in Cur Deus homo. As for the Reformers, in their view Christ's rising from the dead confirms His victory and establishes righteousness, proves His divinity and makes His power available to believers (cf. Luther 1911, WA 40.1. s. 270, 546; Calvin 1960, II.16.13). However they speak of resurrection, they still 
see the crux of God's redeeming work in satisfaction of God's justice through Christ's death on the Cross: "Yet to define the way of salvation more exactly, Scripture ascribes this as peculiar and proper to Christ's death ... But because trembling consciences find repose only in sacrifice and cleansing by which sins are expiated, we are duly directed thither; and for us the substance of life is set in the death of Christ (Calvin, II.16.5; cf. Luther, WA 40.I, s. 281).

5 There has been a lot of discussion over the interpretation of the key concepts of the penal substitution theory, such as 'propitiation/expiation', 'justification', 'justice/righteousness', 'wrath', 'judgment', to mention but a few works on the issue: (Young 1983; Wright 2009; Marshall 2001; Belousek 2011; Lane 2001; Travis 2009).

6 See: (Gunton 2003; Baker and Green 2011).

$7 \quad$ See: (Belousek 2011, pp. 295-99; Fiddes 1989, p. 108; Baker and Green 2011, pp. 83, 174; Smail 2005, p. 87).

8 Recently there have been several attempts to resolve this tension by showing the unity within the Trinitarian relationships. Some suggest that on the Cross the Father identified Himself with the Son to such an extent that He "endured and exhausted his own wrath against human sin" (Jensen 1993, p. 158; see also: Volf 2006, p. 145). Others appeal to the doctrine of divine simplicity, which implies that God's properties cannot contradict each other and are identical with His actions. God is pure act, He is one in His potentiality and actuality, therefore, God's 'discrete' actions in history are based on underlying and transcendent unity (Vidu 2014, p. 259). In other words, though it may appear that in His earthly ministry and the death on the Cross God's Son shows different character, properties, and motivation than His Heavenly Father, in reality they are one and the same (McCall 2012, p. 80, 88-89).Though these arguments seem logically impeccable, they refute what the penal substitution theory itself tries to assert. Namely, if God's justice represents the nature of God Himself, and if this justice being offended by human sin demands satisfaction, then by definition we are dealing with the Divine dissatisfaction and, thus, with some sort of conflict of His attributes. Therefore, it would be more natural to profess-as Luther, Calvin, and other adherers of the satisfaction theory did - that via punishment of His Son, the Father tempers justice with mercy and offers forgiveness to human beings. That is why the dereliction on the Cross motif played a very important role in the Reformers' teaching of the atonement (Luther 1892, WA 5, s. 602-3; Calvin 1960, II.16.11), and since then has become a sine qua non of all penal substitution presentations.

9 See: (Stott 1986, pp. 35, 235, 238; Grudem 1994, pp. 615-16).

10 As some critics have pointed out, the significance of the doctrine of the resurrection is downplayed in contemporary accounts of the doctrine of the atonement. Thus, as Belousek notes (Belousek 2011, p. 110), in a recent extensive (over 450 pages) collection of essays on the atonement (Hill and James III 2004), there are only four brief discussions of Christ's resurrection. Or, as pointed out by Baker and Green (2011, p. 180), J. Packer in his influential essay What Did the Cross Achieve? The Logic of Penal Substitution (Packer 2008) makes no mention of resurrection in listing the most important elements of the penal substitution doctrine.

11 For example: "Not only love and punishment compatible, but the very principle behind the capital punishment is the one that made the cross necessary. It is a principle 'a life for a life'. Concept behind substitutionary atonement, that it takes life to atone for a life (Lev 17:11), is what makes capital punishment necessary for capital crimes. If there were any other way to satisfy justice and release grace, surely God would have found it rather than sacrificing his only beloved Son" (Geisler 1989, p. 197).

12 Immanuel Kant noted that personal moral guilt for sin cannot be transferred from the guilty to the innocent, even if the latter is so benevolent as to take the guilt on himself. Such a situation would be possible within a legal system where one may choose to pay a fine or the debt of the other, but it is not possible within the realm of morality and personal relationships where moral guilt is not a transmissible liability. To say otherwise is to jumble the moral and the legal categories (Kant 1999, pp. 88-89).

13 It is a locus communis among historical theologians to raise concern with regard to the patristic idea of deceiving the devil. Though the New Testament texts clearly tell about messianic misconceptions about Jesus (Lk 24:18-21; Acts 13:27, etc.) or "the secret and hidden wisdom of God" (1 Cor 2:7-8) which was displayed through Christ's crucifixion and, thus, achieved victory over the evil powers, the apostolic authors do not explicate this idea. Later the Church Fathers develop this theme by using various images and metaphors. Whether they used an image of a baited mousetrap, as Augustine, or that of a fishhook, as Gregory of Nyssa and many others did, they were trying to underscore the idea of God's defeat of the devil, victory of life over death, as the evil reality encounters the goodness and divinity of Jesus Christ (for one of the best recent treatments of this patristic imagery see: Lombardo 2014, pp. 198-203). In his presentation of the atonement Finger offers a very convincing explanation of God's "deceit" of the devil: "In other words, the powers could be 'deceived' not because Christ intentionally tricked them but because of their own assumptions about power and how it is exercised ... Jesus' enemies, then, were deceived because they could not imagine that any actual kingdom, especially not one claiming to represent the ultimate deity, could possibly be established in this way" (Finger 1985, p. 333).

\section{References}

Althaus, Paul. 1996. The Theology of Martin Luther. Philadelphia: Fortress Press.

Anselm, Saint. 1903. Cur Deus Homo. In Proslogium; Monologium: An Appendix, In Behalf of the Fool by Gaunilon; and Cur Deus Homo (No. 54). Chicago: Opencourt Publishing Company, pp. 177-288

Aulén, Gustaf. 2003. Christus Victor: An Historical Study of the Three Main Types of the Idea of Atonement. Eugene: Wipf \& Stock Pub.

Baker, Mark D., and Joel B. Green. 2011. Recovering the Scandal of the Cross: Atonement in New Testament E Contemporary Contexts, 2nd ed. Downers Grove: IVP Academic. 
Belousek, Darrin W. Snyder. 2011. Atonement, Justice, and Peace: The Message of the Cross and the Mission of the Church. Grand Rapids: Wm. B. Eerdmans Publishing Company.

Blocher, Henri. 2004. The Atonement in John Calvin's Theology. In The Glory of the Atonement: Biblical, Theological E Practical Perspectives: Essays in Honor of Roger Nicole. Downers Grove: IVP Academic, pp. 279-303.

Boyd, Gregory A. 2006. Christus Victor View. In The Nature of the Atonement: Four Views. Edited by James Beilby and Paul R. Eddy. Downers Grove: IVP Academic, pp. 23-49.

Brown, Joanne Carlson, and Rebecca Parker. 1989. For God So Loved the World? In Christianity, Patriarchy and Abuse: A Feminist Critique. Edited by Brown Joanne C. Berea: Pilgrim Press, pp. 1-30.

Burnell, F. Eckardt. 1992. Anselm and Luther on the Atonement. Was it 'Necessary'? San Francisco: Mellen Research University Press.

Burns, Patout J. 1975. The Concept of Satisfaction in Medieval Redemption Theory. Theological Studies 36: 285-304. [CrossRef]

Bushnell, Horace. 1866. The Vicarious Sacrifice, Grounded in Principles of Universal Obligation. New York: C. Scribner \& Co.

Calvin, John. 1960. Institutes of the Christian Religion. Edited by John T. McNeill. Louisville: Westminster John Knox Press.

Campbell, John MacLeod. 1856. The Nature of the Atonement, and Its Relation to Remission of Sins and Eternal Life. London: Macmillan and Co.

Daniels, T. Scott. 2006. Passing the Peace: Worship That Shapes Nonsubstitutionary Convictions. In Atonement and Violence: A Theological Conversation. Edited by John Sanders. Nashville: Abingdon Press, pp. 125-48.

Fiddes, Paul S. 1989. Past Event and Present Salvation: A Study in the Christian Doctrine of the Atonement. Louisville: Westminster John Knox Press.

Finger, Thomas N. 1985. Christian Theology: An Eschatological Approach. Nashville: Thomas Nelson Publishers, vol. 1.

Finger, Thomas N. 2004. A Contemporary Anabaptist Theology: Biblical, Historical, Constructive. Downers Grove: InterVarsity Press.

Finger, Thomas N. 2006. Christus Victor as Nonviolent Atonement. In Atonement and Violence: A Theological Conversation. Edited by John Sanders. Nashville: Abingdon Press, pp. 87-111.

Finlan, Stephen. 2007. Options on Atonement in Christian Thought. Collegeville: Liturgical Press.

Florovsky, Georges. 1972. Ways of Russian Theology. In The Collected Works. Belmont: Nordland Publishing Company, vol. 6, Part II.

Geisler, Norman L. 1989. Christian Ethics: Options and Issues. Grand Rapids: Baker Academic.

Grudem, Wayne. 1994. Systematic Theology. Grand Rapids: Zondervan.

Gunton, Colin E. 2003. The Actuality of Atonement: A Study of Metaphor, Rationality, and the Christian Tradition. London: T\&T Clark.

Hannah, John D. 1978. Anselm on the Doctrine of Atonement. Bibliotheca Sacra 135: 333-44.

Helm, Paul. 2008. Calvin: A Guide for the Perplexed. London: T\&T Clark.

Hill, Charles E., and Frank A. James III, eds. 2004. The Glory of the Atonement: Biblical, Theological E Practical Perspectives: Essays in Honor of Roger Nicole. Downers Grove: IVP Academic.

Irenaeus, Saint. 1885. Against Heresies. In Ante-Nicene Fathers: The Writings of the Fathers down to A.D. 325. New York: Christian Literature Publishing Co., vol. 1.

Jeffery, Steve, Michael Ovey, and Andrew Sach. 2007. Pierced for Our Transgressions: Rediscovering the Glory of Penal Substitution. Wheaton: Crossway.

Jensen, Paul. 1993. Forgiveness and Atonement. Scottish Journal of Theology 46: 141-60. [CrossRef]

Kant, Immanuel. 1999. Religion within the Boundaries of Mere Reason: And Other Writings. Cambridge: Cambridge University Press.

Lane, Tony. 2001. The Wrath of God as an Aspect of the Love of God. In Nothing Better, Nothing Greater: Theological Essays on the Love of God. Edited by Kevin J. Vanhoozer. Grand Rapids: Wm. B. Eerdmans Publishing Company, pp. 138-67.

Lombardo, Nicholas. 2014. The Father's Will: Christ's Crucifixion and the Goodness of God. New York: Oxford University Press.

Luther, Martin. 1892. Operationes in Psalmos, 1519-1521. Psalmus vicesimus primus, hebraeis XXII. In D. Martin Luthers Werke: Kritische Gesamtausgabe. Weimar: Hermann Böhlaus Nachfolger, vol. 5, pp. 598-672.

Luther, Martin. 1888. Tessaradecas Consolatoria Pro Laborantibus et Oneratis 1520. In D. Martin Luthers Werke: Kritische Gesamtausgabe. Weimar: Hermann Böhlaus Nachfolger, vol. 6, pp. 99-134.

Luther, Martin. 1911. In epistolam St. Pauli ad Galatas Commentarius ex praelectione D. Martini Lutheri collectus [1531.] 1535. In D. Martin Luthers Werke: Kritische Gesamtausgabe. Weimar: Hermann Böhlaus Nachfolger, vol. 40.I, pp. 1-688.

Marshall, Christopher D. 2001. Beyond Retribution: A New Testament Vision for Justice, Crime, and Punishment. Grand Rapids: Wm. B. Eerdmans Publishing Company.

McCall, Thomas H. 2012. Forsaken: The Trinity and the Cross, and Why It Matters. Downers Grove: IVP Academic.

Moberly, Robert Campbell. 1901. Atonement and Personality. London: John Murray.

Packer, James I. 2008. What Did the Cross Achieve? The Logic of Penal Substitution. In My Place Condemned He Stood: Celebrating the Glory of the Atonement. Edited by James I. Packer and Mark Dever. Wheaton: Crossway, pp. 53-100.

Pelikan, Jaroslav. 1985. Reformation of Church and Dogma (1300-1700). In The Christian Tradition: A History of the Development of Doctrine. Chicago and London: University of Chicago Press, vol. 4.

Rashdall, Hustings. 1919. The Idea of Atonement in Christian Theology. London: Macmillan.

Ray, Darby Kathleen. 1998. Deceiving the Devil: Atonement, Abuse, and Ransom. Cleveland: Pilgrim Press.

Ritschl, Albrecht. 1872. A Critical History of the Christian Doctrine of Justification and Reconciliation. Edinburgh: Edmonston \& Douglas.

Schmiechen, Peter. 2005. Saving Power: Theories of Atonement and Forms of the Church. Grand Rapids: Wm. B. Eerdmans Publishing Company. 
Smail, Tom. 2005. Once and for All: A Confession of the Cross. Eugene: Wipf \& Stock Pub.

Stott, John R. W. 1986. The Cross of Christ. Downers Grove: IVP Books.

Travis, Stephen H. 2009. Christ and the Judgement of God: The Limits of Divine Retribution in New Testament Thought. Colorado Springs: Hendrickson Publishers.

Vidu, Adonis. 2014. Atonement, Law, and Justice: The Cross in Historical and Cultural Contexts. Grand Rapids: Baker Academic.

Volf, Miroslav. 2006. Free of Charge: Giving and Forgiving in a Culture Stripped of Grace. Grand Rapids: Zondervan.

Weaver, J. Denny. 2006. Narrative Christus Victor: The Answer to Anselmian Atonement Violence. In Atonement and Violence: A Theological Conversation. Edited by John Sanders. Nashville: Abingdon Press, pp. 1-29.

Weaver, J. Denny. 2011. The Nonviolent Atonement, 2nd ed. Grand Rapids: Wm. B. Eerdmans Publishing Company.

Williams, J. Garry. 2011. Penal substitutionary atonement in the Church Fathers. Evangelical Quarterly 83.3: 195-216.

Wright, Nicholas T. 2009. Justification: God's Plan \& Paul's Vision. Downers Grove: IVP Academic.

Young, Norman. 1983. "Hilaskesthai" and Related Words in the New Testament. Evangelical Quarterly 5: 169-76. 